\title{
The significance of a Middle Devonian K/Ar age of an intrusive rock in the southern part of the North Greenland Fold Belt
}

\author{
STIG A. SCHACK PEDERSEN and PAUL MARTIN HOLM
}

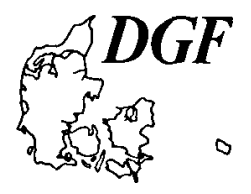

\begin{abstract}
Pedersen, S. A. S. \& Holm, P. M. The significance of a Middle Devonian K/Ar age of an intrusive rock in the North Greenland Fold Belt. Bull. geol. Soc. Denmark, vol. 31, p. 121-127, Copenhagen, March 7th, 1983. https://doi.org/10.37570/bgsd-1982-31-09

A K/Ar age of $380 \pm 5 \mathrm{Ma}$ has been obtained from an intrusive body in the southern part of the North Greenland Fold Belt in Peary Land. This age dates the first major deformation event in the North Greenland Fold Belt, and it is inferred that a correlation exists between the North Greenland Fold Belt and the Northern Ellesmerian Fold Complex of the Arctic Canadian archipelago. The dating furthermore casts serious doubt on the proposed genetic link between the intrusive rocks of the southern part of the North Greenland Fold Belt and the Late Cretaceous Kap Washington volcanics and the $\mathbf{N}-\mathrm{S}$ trending dyke swarms W of Peary Land.
\end{abstract}

Stig A. Schack Pedersen and Paul Martin Holm, Geologisk Centralinstitut, Øster Voldgade 10, DK-1350 København K, Denmark, 29th September, 1982.

\section{Introduction}

Intrusive bodies in the southern part of the North Greenland Fold Belt were discovered in 1979 during the Geological Survey of Greenlands expedition to Peary Land (Pedersen 1980, Soper et al. 1980). One of the most prominent intrusive bodies was first observed at the mountain Midtkap, north of Frederick E. Hyde Fjord (Fig. 1, 2 \& $3)$, and the intrusives are hereafter referred to as the Midtkap Igneous Complex. Rocks of the Midtkap Igneous Complex are situated south of the large E-W trending Harder Fjord Fault Zone (HFFZ) that separates the southern North Greenland Fold Belt from the northern part.

The southern part of the fold belt has been affected by two very different orogenic events: 1 ) the Vølvedal Orogeny which is connected to the Caledonian mobile belt (Pedersen 1981, 1982, Håkansson \& Pedersen in press) and 2) the Ellesmerian Orogeny which is the major deformation event in the Innuitian belt (Christie 1979, Trettin \& Balkwill 1979, Higgins et al. 1981, Pedersen 1981).

In this paper a K/Ar date on the Midtkap Igenous Complex is presented, and its significance is discussed in relation to (1) the fold belt deformations, (2) the activation of the Harder
Fjord Fault Zone and a correlation with the northern Ellesmerian Fold Complex (Trettin \& Balkwill 1979).

\section{The North Greenland Fold Belt in Peary Land}

The northernmost land area in Greenland is occupied by the E-W trending Palaeozoic North Greenland Fold Belt. Historical aspects of the geological investigations of this remote region is given by Dawes $(1971,1976)$.

The rocks of the fold belt consist of shales, turbidites and redeposited conglomerates (Frederichsen et al. 1982). South of the fold belt Lower Palaeozoic platform carbonates overlain by Silurian flysch (Christie \& Peel 1977) form the hinterland to the fold belt (Ellitsgaard-Rasmussen 1955). During Cambro-Ordovician times the platform margin gradually collapsed concomitant with the development of the North Greenland clastic sedimentary trough (Surlyk et al. 1980). It is significant that the southern margin of the fold belt and the northern edge of the carbonate platform is a coincident zone situated $5-10 \mathrm{~km}$ south of the deeply, E-W incised Frederick E. Hyde Fjord (Fig. 2). 


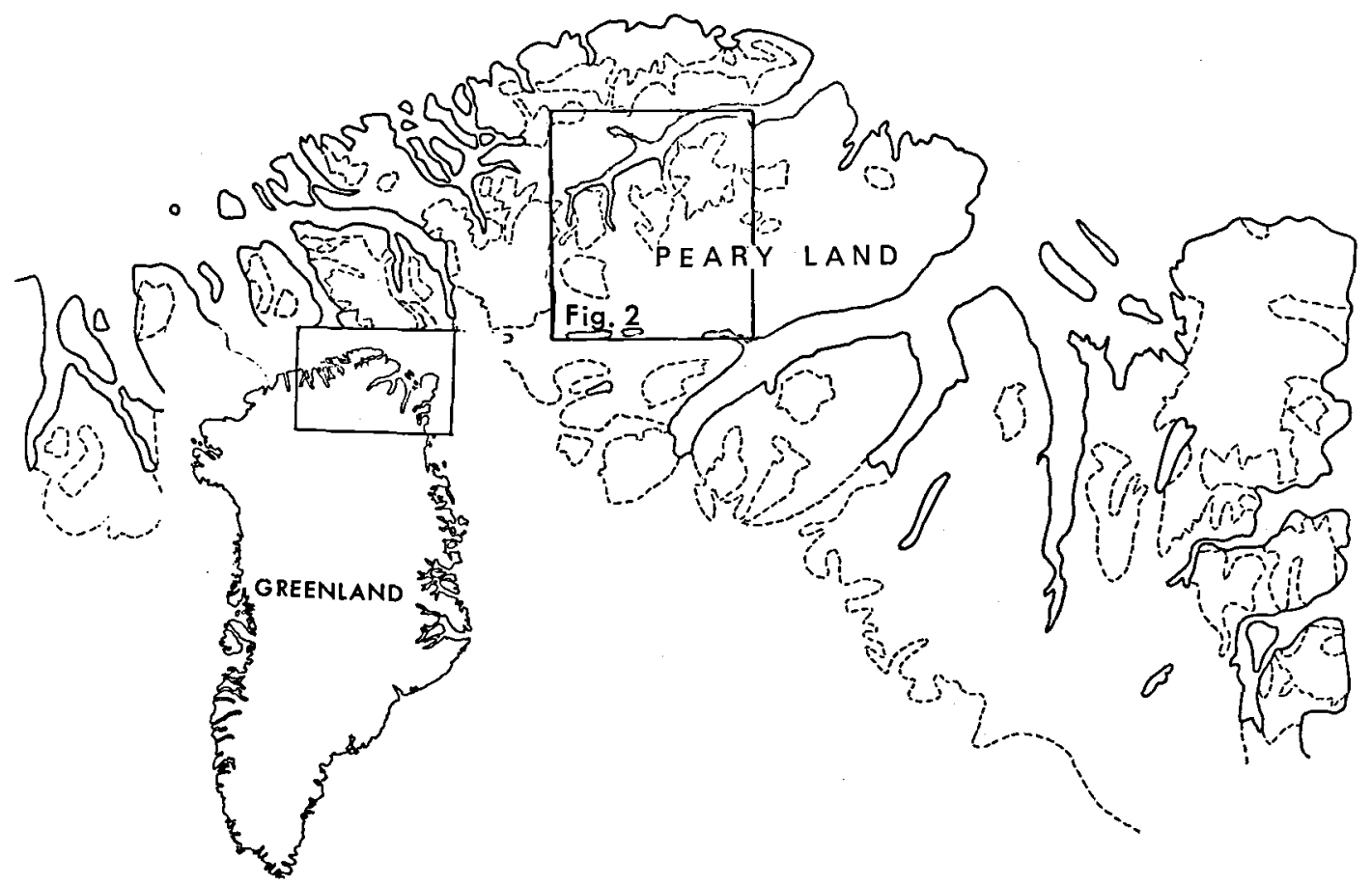

Fig. 1. Location map of Peary Land, North Greenland. The position of the block diagram Fig. 2 is framed.

Dawes and Soper $(1973,1979)$ divided the fold belt into five E-W trending structural zones reflecting increasing deformation and metamorphosis from south to north. More detailed mapping in the northern part of the region (Soper et al. 1980, Higgins et al. 1981) confirms the general structural trends E-W outlined by Fränkl (1955), Ellitsgaard-Rasmussen (1955), Dawes (1971, 1976) Dawes and Soper $(1973,1979)$. Three Ellesmerian fold phases are recognized in the main fold belt region (Soper et al. 1980, Higgins et al. 1981).

The southern part of the fold belt corresponds to zone 1 and 2 of Dawes and Soper $(1973,1979)$ and it is bordered to the north by the transcurrent Harder Fjord Fault Zone (HFFZ, Fig. 2 \& 3). Recent fieldwork in the North Greenland Fold Belt (Pedersen 1980) has shown that there is a marked structural difference between the southern and the northern part of the fold belt. Two orogenies have affected this area. The first is a thin skinned decollement deformation with thrust faulting and folding directed towards the west (Pedersen 1980, 1981) and named the Vølvedal Orogeny by Pedersen (1982). The Vølvedal Oro- geny is interpreted as gravity thrusting and megasliding related to elevation of the Caledonides in eastern North Greenland (Pedersen 1981). The second deformation belongs to the Ellesmerian Orogeny and corresponds to the first $\left(F_{1}\right)$ fold phase recognized in the main fold belt region (Soper et al. 1980, Higgins et al. 1981). In the southern part of the fold belt the structures of the Ellesmerian deformation are macroscopic upright synclines and anticlines trending E-W and the rocks display little or no metamorphic alteration. Due to the Ellesmerian deformation the structures of the Vølvedal Orogeny are refolded and initially flatlying thrust faults are tilted into steeply dipping positions.

\section{The Midtkap Igneous Complex}

The intrusive centres of the Midtkap Igenous Complex are distributed over an area of c. 300 $\mathrm{km}^{2}$ situated in the triangle bordered by Frigg Fjord, Frederick E. Hyde Fjord and the Harder Fjord Fault Zone, (Fig. 3). The intrusive rocks are discordantly emplaced in the Cambrian (?) 


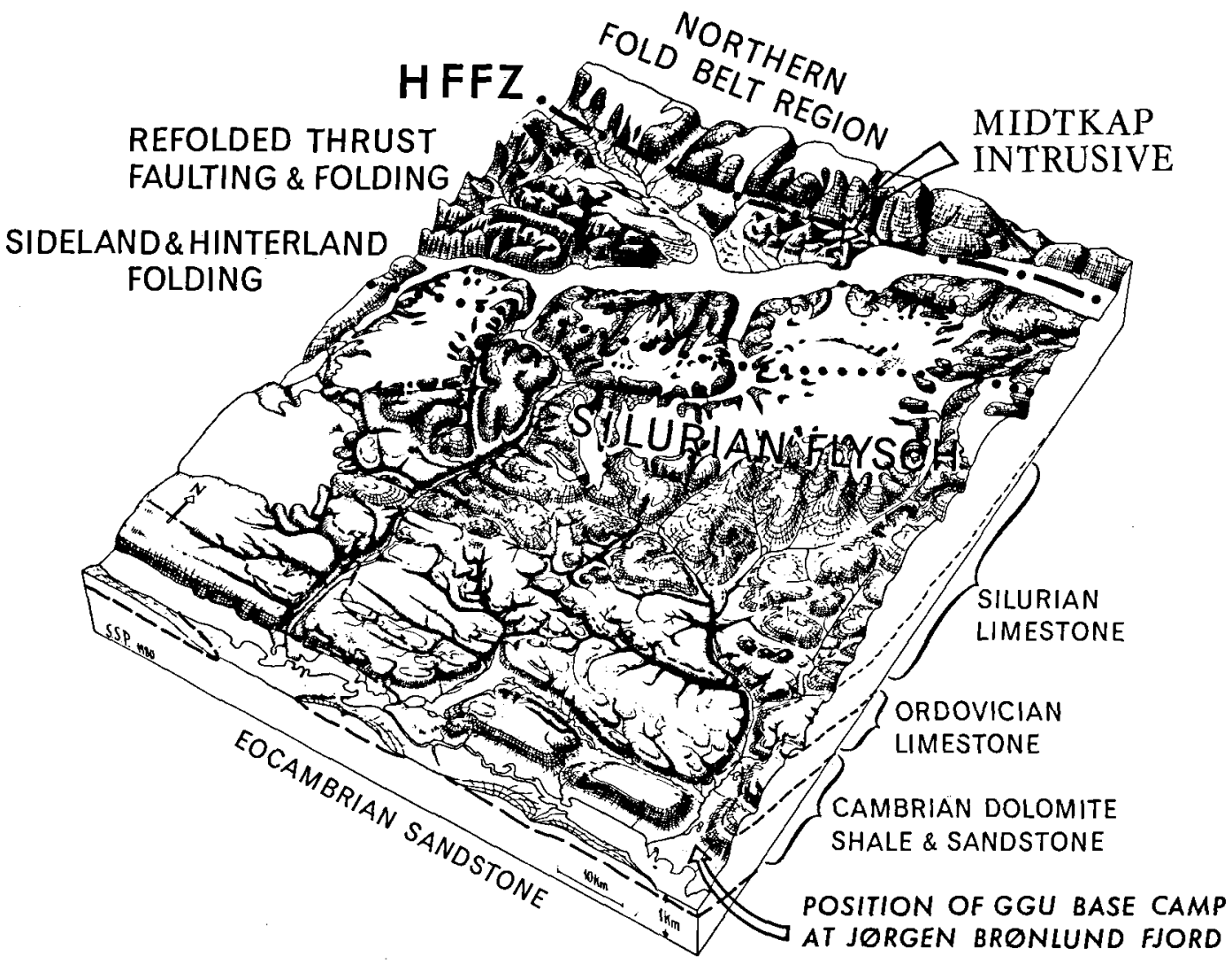

Fig. 2. Topographic block diagram of central Peary Land illustrating the main geological divisions in the transition from Lower Palaeozoic carbonate platform into folded Lower Palaeozoic trough sediments in the fold belt region.

HFFZ is the Harder Fjord Fault Zone which separates the southern part of the fold belt from the northern fold belt region. Frederick E. Hyde Fjord is the long fjord in the upper part of the block diagram from which Frigg Fjord stretches to the NW.

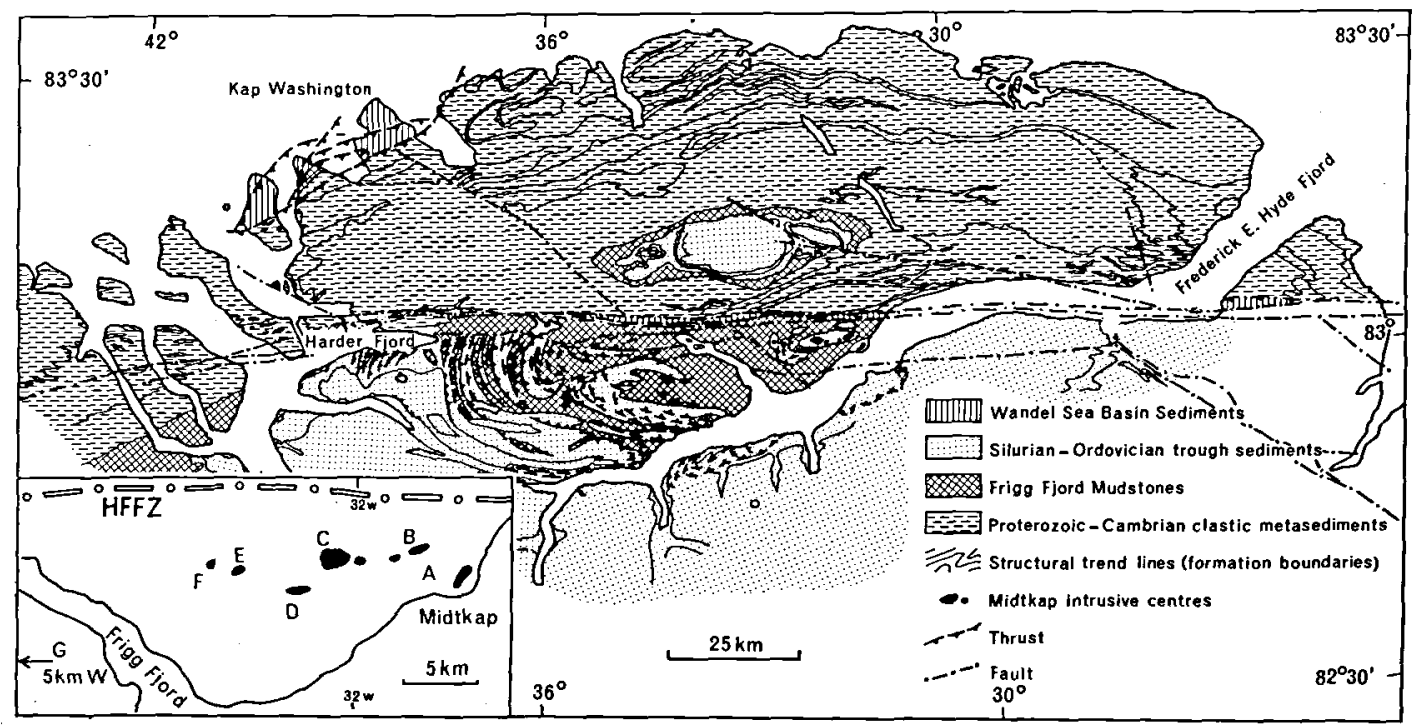

Fig. 3. Geological map of the fold belt region in Peary Land, North Greenland. 
Frigg Fjord Mudstone and the Ordovician clastic sediments. Six intrusive centres (A-F, Fig. 3) have been described from the area (Pedersen 1980, Soper et al. 1980, Parsons 1981) and an additional intrusive breccia situated $8 \mathrm{~km}$ SW of Frigg Fjord (G, Fig. 3) is regarded as being related to the complex (Pedersen 1980).

The rock types presented in the intrusive centres are serpentinite, diorite, dioritic gabbro, micro-diorite, leucocratic granite, agglomerates and agglomeratic breccias (Pedersen 1980, Soper et al. 1980, Parsons 1981). In some of the centres amphibolitic gneisses and brecciated metamorphic basement rocks occur (Soper et al. 1980, Parsons 1981), and in the agglomerates spilitic rocks similar to pillow-lavas situated in the HFFZ north of Midtkap have been observed (Parsons 1981). In many places it has been observed that the intrusives were affected by shearing in a deformation postdating the igneous emplacement (Pedersen 1980, Parsons 1981), although the primary intrusive contacts have not been obliterated.

The geological setting of the intrusive centres has been discussed by Pedersen (1980), Soper et al. (1980) and Parsons (1981). Pedersen (1980) suggests an syntectonic emplacement due to the shear structure observed in centres $A$ and $G$ which are orientated parallel to the general N-S orientated Vølvedal orogenic trend. Soper et al. (1980) regard the intrusions as post-tectonic, related to the tectonics of the HFFZ, and states (due to the occurrences of basement xenoliths) that the Lower Palaeozoic clastic trough developed on an ensialic basement close to a continental margin. Parsons (1981) describes the serpentinites as deformed before emplacement, but the emplacement of the intrusive rock as posttectonic. A correlation with the Kap Washington Group volcanics (Dawes 1976, Larsen et al. 1978, Soper et al. 1980, Brown \& Parsons 1981) is suggested by Parsons (1981) although relations to spillites in the HFFZ and to a marginal oceanfloor assemblage in the turbidites beneath Frigg Fjord Mudstones are additionally discussed.

\section{Analytical techniques}

One whole rock sample from centre $\mathrm{A}$ at Midtkap was dated by the K/Ar-method. The sample was crushed and sieved, the $125 \mu \mathrm{m}-250 \mu \mathrm{m}$ size fraction being used for both $\mathrm{K}$ and Ar determination. Potassium was determined in triplicate by flame photometry using a Perkin-Elmer model 460 Atomic Absorption Spectrophotometer and a sample solution with a lithium buffer. Ar was extracted by total fusion by induction heating in a high vacuum system and determined by isotope dilution at the Institute of Petrology, University of Copenhagen. The system was calibrated with atmospheric argon and international standards (P-207 and LP-6). A three stage purification procedure was used: stage one incorporating a Tisponge furnace and a liquid nitrogen trap; stage two pumping away of $\mathrm{H}_{2}$ and a second Ti-sponge furnace; and stage three pumping of active gasses in the mass-spectrometer of two $\mathrm{Zr}-\mathrm{Al}$ getterpumps. A small aliquot of the gas was tested in the mass-spectrometer before letting in the gas sample for Ar-analysis. The mass-spectrometer was an AEI MS10 fitted with a 1.8 kgauss permanent magnet, and the results recorded on a chart. Decay constants and branchsing ratio for ${ }^{40} \mathrm{~K}$ after Steiger and Jäger (1977) were used, the data were reduced by a computer program and the Ar ratios at time of inlet of gas into the massspectrometer are calculated. The results were corrected for mass discrimination, isotope fractionation and line blank.

\section{Petrography and interpretation}

The specimen, GGU 217863, is a fine-grained intermediate magmatic rock which exhibits multiple metamorphic alteration of the primary minerals. Part of the magmatic andesitic paragenesis can be recognized: euhedral and subhedral phenocrysts of plagioclase, hornblende and biotite with accessory zircon. Mica has extensively been altered to chlorite. Almost all hornblende is recrystallized to green actinolitic amphibole, and signs of a third generation of amphibole is seen. A uralitized mineral is also present which probably represents magmatic clinopyroxene. The plagioclase has two generations of which the former is nearly completely resorbed and replaced by muscovite. The late plagioclase generation rims the muscovite pseudomorphic phenocrysts and is a groundmass constituent $\left(\mathrm{An}_{55}-\mathrm{An}_{20}\right.$ normal zonation). Quartz is present in the mesostasis. 
Table 1. Result of the K/Ar-analysis of micro diorite from centre A of the Midtkap Igneous Complex.

\begin{tabular}{|c|c|c|c|c|c|}
\hline \multirow[t]{2}{*}{ Sample no. } & \multirow[t]{2}{*}{$\mathbf{K}$} & \multirow{2}{*}{$\begin{array}{l}{ }^{40} \mathrm{Ar}_{\mathrm{rad}} \\
\mathrm{mol} \mathrm{g}^{-1}\end{array}$} & \multirow{2}{*}{$\%$ of tot ${ }^{40} \mathrm{Ar}$} & \multicolumn{2}{|c|}{ Calculated age } \\
\hline & & & & $\mathrm{Ma}$ & $\pm 1 \sigma$ \\
\hline GGU 217863 & 1.35 & $9.87 \times 10^{10}$ & 98.1 & 380 & \pm 5 \\
\hline
\end{tabular}

The conservation of the magmatic texture and the metamorphic alteration products (biotite $\rightarrow$ chlorite, hornblende $\rightarrow$ actinolite, feldspar $\rightarrow$ muscovite) suggest a retrograde contact-metamorphism dominantly of the greenschist facies, which was not sufficiently intense to obliterate the primary magmatic mineral assemblage.

The rock was intruded into poorly consolidated Cambro-Ordovician clastic sediments. The heat flow from the intrusive body into the surroundings probably provoked a very effective convective system of meteoric waters in the highly permeable country rock. As no regional metamorphic event took place in the area considered and no stress effects are observed on the rock specimen, we think that most likely the magmatic paragenesis was changed during the cooling of the pluton by the favourable conditions for fast chemical reactions during a hydrothermal regime.

The K/Ar date is largely dependent on four potassium-bearing minerals in the rock: biotite, hornblende, plagioclase and muscovite-bearing pseudomorphs after plagioclase. The rest only contribute very minor amounts of ${ }^{40} \mathrm{Ar}_{\text {rad }}$. Hornblende normally retains argon at temperatures below c. $550^{\circ} \mathrm{C}$ (Harrison 1981), and thus would yield a result closest to the time of intrusion of the magma. However, only minor amounts (less than $1 \%$ ) of this phase is preserved. Both biotit and muscovite (together they account for more than $90 \%$ of the potassium) are expected to give the approximate age of the cooling below the temperatures c. $250^{\circ} \mathrm{C}-300^{\circ} \mathrm{C}$ (Harrison \& mcDougall 1980) dependent on the cooling rate, provided they were totally reset with respect to ${ }^{40} \mathrm{Ar}_{\mathrm{rad}}$ content during the latest heating. Both muscovite and plagioclase are thought to have been formed during the metamorphism and probably give an age near to that of their formation. There is no evidence of any significant alteration subsequent to this retrograde metamorphism.

It is therefore concluded that the K/Ar age most likely reflects the latest cooling from greenschist facies temperatures. Only hornblende might give an older age, but would contribute very little to the total rock age. The adopted model for the genesis of the dated rock implies the age of intrusion is not very different from that of the metamorphism, and thus the apparent age is regarded as representing a real event.

\section{Discussion}

The first radiometric age determination obtained from the Midtkap Igneous Complex relates the intrusive event in the southern part of the North Greenland Fold Belt to the earliest orogenic deformation, the Vølvedal Orogeny. Further speculations concerning a connection to the Late Cretaceous Kap Washington Group volcanics and the Late Mesozoic N-S trending dyke swarms in the archipelago west of Peary Land (Higgins et al. 1981, Batten et al. 1981) should thus be rejected.

The $380 \mathrm{Ma} \mathrm{K} / \mathrm{Ar}$ age predates an Early Carboniferous $\mathrm{Rb} / \mathrm{Sr}$ age determination of the structural-metamorphic event in the central part of the fold belt. Here Springer (1982) investigated low grade metamorphic slates and shales from the Cambrian Polkorridoren Group (Friderichsen et al. 1982). $\mathrm{Rb}-\mathrm{Sr}$ dates on the fine fraction $(<2$ $\mu \mathrm{m})$ gave ages of $332 \mathrm{Ma}, 339 \mathrm{Ma}$, and $345 \mathrm{Ma}$ (Springer 1982), which are the first radiometric ages of the Ellesmerian Orogeny in the North Greenland Fold Belt.

The shearing that affected parts of the intrusive rocks reflects a post intrusive deformational event that is connected with the Volvedal Orogeny. The thermal retrograde metamorphic alterations might well be contemporaneous with the thrust fault deformation, during which high mobility of volatiles is considered present in connection with release of high pore pressure due to the gravity sliding of the sediment slices. In the regional distribution of the intrusives it is characteristic that they occur in the eastern part of the Vølvedal Orogeny area. Here most of the cover down to the Frigg Fjord Mudstones has been peeled off, 
and it is likely that the intrusives had broken through the "roof" where there was a minimum thickness of overburden. Hence it is suggested that the intrusive event was syntectonic, as igneous bodies were affected by the deformation, and late syntectonic as they intruded the easternmost "thin-covered" area, from where the westernly displaced thrust sheets first had to be removed.

The nearest igneous and structural province within the Innuitian Mobile Belt that might be correlatable with the Midtkap area is the Northern Ellesmere Fold Complex situated in North Canada about $500 \mathrm{~km}$ west of Peary Land. The Northern Ellesmere Fold Complex consists of Lower Palaeozoic and Proterozoic sediments and meta-sediments thrust faulted and folded towards the southwest and intruded by gabbros, diorites and serpentinites (Trettin \& Balkwill 1979). The intrusives yield ages of 390, 376, 360 and $345 \mathrm{Ma}$ which are regarded as syntectonic with the main Palaeozoic deformation event in the Innuitian Mobile Belt (Trettin \& Balkwill 1979). Christie (1979) refers the $360 \mathrm{Ma}$ age to the Acadian orogeny and correlates the radiometric dates with the Middle Devonian clastic sedimentation.

Håkansson and Pedersen (in press) present $\mathrm{a}$ speculative mobilistic model of the correlation between the Vølvedal Orogeny and the Northern Ellesmere Fold Complex. According to this model the two regions originally represented a coherent N-S trending thrust fault and fold belt that was torn apart by a sinistral transcurrent fault along the HFFZ in the Late Devonian to Early Carboniferous time. The $380 \mathrm{Ma} \mathrm{K} / \mathrm{Ar}$ dating of the Midtkap Igneous Complex supports a correlation of the two regions. The suggested sinistral displacement (Håkansson \& Pedersen, in press) is about $700 \mathrm{~km}$ with a direction towards WNW west of Peary Land (Håkansson \& Pedersen in press). A dextral displacement of c. $200 \mathrm{~km}$ along HFFZ with WSW strike west of Peary Land is regarded to have brought the northern part of the fold belt into its present position (Håkansson \& Pedersen in press).

\section{Conclusion}

A whole rock $\mathrm{K} / \mathrm{Ar}$ age of $380 \pm 5 \mathrm{Ma}$ has been obtained from an intrusive micro-diorite from the Midtkap Igneous Complex in the southern part of the North Greenland Fold Belt. The intrusives are interpreted as syntectonic with the Vølvedal Orogeny which is thus regarded as Middle Devonian.

The Middle Devonian age of the Midtkap Igneous Complex rejects any speculation of a correlation with Late Mesozoic igneous activity in the northern part of the North Greenland Fold Belt.

A correlation with intrusive rocks of the Northern Ellesmere Fold Complex is suggested supporting a hypothesis of a Late Devonian sinistral transcurrent strike slip displacement of about 700 $\mathrm{km}$.

Acknowledgements. This paper is published with the permission of the Director of The Geological Survey of Greenland. C. K. Brooks kindly read an earlier draft of the paper and offered helpfull suggestions. Both authors held a grant from the University of Copenhagen which is gratefully acknowledged, and the analytical facilities were financed by the Danish Natural Science Research Council.

\section{Dansk sammendrag}

En K/Ar alder på 380 mill. år er opnået ved datering af en micro-diorite fra det intrusive kompleks ved Midtkap i den sydlige del af det Nordgrønlandske Foldebælte. To regionale orogene deformationer har påvirket de nedre palæozoiske klastiske sedimenter i den sydlige del af foldebæltet: 1) en tidlig vestrettet gravitativ udglidnings- og overskydningstektonik, der er relateret til hævningen af Caledoniderne i det østlige Nordgrønland, 2) en N-S rettet kompressiv orogen tektonik, som skabte den dominerende foldning i det Innuitiske Foldebælte, der kendes fra Peary Land i ost til Ellesmere Island (Nord Canada) $i$ vest. Intrusionerne ved Midtkap tolkes som syn-tektoniske og tilknyttede den tidlige overskydningsdeformation. Den radiometriske datering angiver således en mellem Devon alder af såvel den første deformationsfase som af intrusionerne i den sydlige del af det Nordgrønlandske Foldebælte. Intrusionerne og overskydningsdeformationerne foreslås korreleret med Northern Ellesmere Fold Complex i Nord Canada, hvor lignende radiometriske aldre er opnået på intrusive bjergarter. Den radiometriske datering underbygger en hypotese om, at dette område oprindelig var nærmere tilknyttet Peary Land, men er blevet fortsat ved en sinistral bevægelse på c. $700 \mathrm{~km}$ mod vest langs Harder Fjord Forkastnings Zonen.

\section{References}

Batten, D. J., Brown, P. E., Dawes, P. R., Higgins, A. K., Eske Koch, B., Parsons, I. \& Soper, N. J. 1981: Peralkaline volcanicity on the Eurasia Basin margin. Nature 294, 150-152.

Brown, P. E. \& Parsons, I. 1981: The Kap Washington Group volcanics. Rapp. Gronlands geol. Unders. 106, 65-68.

Christie, R. L. 1979: The Franklinian Geosyncline in the Canadian Arctic and its relationship to Svalbard. Norsk Polarinstitutt Skrifter 167, 263-314. 
Christie, R. L. \& Peel, J. 1977: Cambrian-Silurian stratigraphy of Børglum Elv, Peary Land, eastern North Greenland. Rapp. Grønlands geol. Unders. 82, 48 pp.

Dawes, P. R. 1971: The North Greenland fold belt and environs. Bull. geol. Soc. Denmark 20, 197-239.

Dawes, P. R. 1976: Precambrian to Tertiary of northern Greenland. In Escher, A. \& Watt, W. S. (eds) Geology of Greenland, 249-303. Copenhagen: Geol. Surv. Greenland.

Dawes, P. R. \& Soper, J. 1973: Pre-Quarternary history of North Greenland. In Pitcher, M. G. (ed.) Arctic Geology. Mem. Amer. Ass. Petrol. Geol. 19, 117-134.

Dawes, P. R. \& Soper, J. 1979: Structural and stratigraphic framework of the North Greenland fold belt in Johannes V. Jensen Land, Peary Land. Rapp. Gronlands geol. Unders. $93,40 \mathrm{pp}$.

Ellitsgaard-Rasmussen, K. 1955: Features of the geology of the folding range of Peary Land, North Greenland. Meddr Gronland 127 (7), $56 \mathrm{pp}$.

Friderichsen, J. D., Higgins, A. K., Hurst, J. M., Pedersen, S. A. S., Soper, N. J. \& Surlyk, F. 1982: Lithostratigraphic framework of the Upper Proterozoic and Lower Palaeozoic deep water clastic deposits of North Greenland. Rapp. Gronlands geol. Surv. 107, 20 pp.

Fränkl, E. 1955: Rapport über die Durchquerung von Nord Peary Land (Nordgrönland) in sommer 1953. Meddr Grønland 103 (8), $61 \mathrm{pp}$.

Harrison, T. M. 1981: Diffusion of ${ }^{40} \mathrm{Ar}$ in hornblende. CMP $78,324-331$.

Harrison, T. M. \& MacDougall, I. 1980: Investigations of an intrusive contact, northwest Nelson, New Zealand - I Thermal, Chronological and isotopic constraints. Geochem. Cosmochem. Acta 44, 1985-2004.

Higgins, A. K., Friderichsen, J. D. \& Soper, N. J. 1981: The North Greenland fold belt between central Johannes V. Jensen Land and Eastern Nansen Land. Rapp. Gronlands geol. Unders. 106, 35-45.
Håkansson, E. \& Pedersen, S. A. S. in press: Late Paleozoic to Tertiary tectonic evolution of the continental margin in North Greenland. Can. Soc. Petrol. Geol. Memoir 8, Arctic Geology and Geophysics.

Larsen, O., Dawes, P. R. \& Soper, N. J. 1978: Rb/Sr age of the Kap Washington Group, Peary Land, North Greenland, and its geo-tectonic implication. Rapp. Gronlands geol. Unders. 90, 115-119.

Parsons, I. 1981: Volcanic centres between Frigg Fjord and Midtkap, eastern North Greenland. Rapp. Grønlands geol. Unders. 106, 69-75.

Pedersen, S. A. S. 1980: Regional geology and thrust fault tectonics in the southern part of the North Greenland fold belt, North Peary Land. Rapp. Grønlands geol. Unders. 99, 79-87.

Pedersen, S. A. S. 1981: Thrust fault tectonics along the Palaeozoic continental margin of North Greenland: the westernmost structural effect of the Caledonian orogenesis. USC abstract 130 in Terra Cognita 1, p. 72.

Pedersen, S. A. S. 1982: Structural analysis of the southern margin of the North Greenland Fold Belt in Peary Land. Unpubl. PhD Thesis, University of Copenhagen.

Soper, N. J., Higgins, A. K. \& Friderichsen, J. D. 1980: The North Greenland fold belt in eastern Johannes V. Jensen Land. Rapp. Grønlands geol. Unders. 99, 89-98.

Springer, N. 1982: $\mathrm{Rb}-\mathrm{Sr}$ age determinations on low-grade meta-sediments from the North Greenland fold belt. Terra Cognita 2, p. 63.

Steiger, R. H. \& Jäger, E. 1977: Subcommission on geochronology: Convention on the use of decay constants in geo- and cosmochronology. EPSL 36, 359-362.

Surlyk, F., Hurst, J. M. \& Bjerreskov, M. 1980: First age-diagnostic fossils from the central part of the North Greenland fold belt. Nature 286, 800-803.

Trettin, H. P. \& Balkwill, H. R. 1979: Contributions to the tectonic history of the Innuitian Province, Arctic Canada. Can. J. Earth Sci. 16, 748-769. 